\title{
NUTRITIONAL COMPOSITION AND STORAGE STABILITY OF GROUNDNUT (ARACHIS HYPOGAEA L.) SEEDS CULTIVATED WITH ORGANIC FERTILIZERS
}

\author{
I Brintha $^{1}$, T Mahendran ${ }^{2 *}$ and TH Seran ${ }^{1}$ \\ ${ }^{1}$ Department of Crop Science, Faculty of Agriculture, Eastern University of Sri Lanka \\ ${ }^{2 *}$ Department of Agricultural Chemistry, Faculty of Agriculture, Eastern University of Sri Lanka
}

Accepted: $04^{\text {th }}$ September 2014

\begin{abstract}
A research study was conducted to determine the nutritional composition and storage stability of groundnut seeds (Arachis hypogaea L.) that were cultivated with organic fertilizers. The mature seeds were collected separately from groundnut plant grown with inorganic and organic fertilizers as basal and organic liquid fertilizer, known as Amuthakaraisal (mixture of cow dung, urine and molasses) applied as top dressing at different vegetative growth stages of groundnut. The collected seeds were dried and stored for further analysis. Protein, fat, moisture, fiber, total soluble solid and mineral contents were determined using the standard methods. The results revealed that there were significant differences $(P<0.05)$ in protein, fat, fiber and total soluble solid content of the groundnut and there were no significant differences $(P>0.05)$ in moisture and mineral contents among treatments while acid value and saponification value of the groundnut oil differed significantly $(P<0.01)$. Based on the results of the nutritional composition of the seeds and physic-chemical aspects of the oil, the organic liquid fertilizer applied at 15, 30, 45 days after planting produce high nutritional quality and storage stability seeds compared with other tested treatments.
\end{abstract}

Key words: Acid value, Groundnut, Nutrients, Organic liquid fertilizer, Saponification value

\section{INTRODUCTION}

Proper nutrition is very important for good human health which is related to the consumption pattern and nutritional value of the diet. Food provides energy for daily activity and maintains body functions. Daily consumption of protein is less than two thirds and fat is less than one third of the level in diet in the developing countries (Woodroof, 1983). Malnutrition is a chronic problem in children as well as adults in developing countries. Formulation of nutritionally balanced food for the vulnerable group is one of the ways to eradicate malnutrition of the growing population. In developing countries, food crops play a vital role in daily diet than animal products. Knowledge on the nutrition value of crop products is necessary in order to encourage cultivation of highly nutritive crops.

Groundnut (Arachis hypogaea L.) is a widely distributed and easily cultivated annual legume plant that belongs to family Leguminacea, principally for its edible oil and protein rich kernels seeds. It can adapt to a wide range of climatic conditions. The nuts are eaten as raw, roasted, steamed or fried form. Groundnut seeds make an important contribution to the diet in many countries. In Sri Lanka, it is mainly used for the manufacture of different varieties of confectionaries. Groundnut seeds contain $44-56 \%$ oil and $22-30 \%$ protein on a dry seed basis and are a rich source of minerals such as phosphorus, calcium, magnesium and potassium and vitamins A, E, K and B group (Savage and Keenan, 1994). Groundnut is grown worldwide primarily for its oil seed and the seeds contain approximately $40 \%$ oil which is twice the amount in soybeans (Bansal et al. 1993). According to Ayoola and Adeyeye (2010) groundnut provides an inexpensive source of high quality dietary protein and oil.

Organic farming is popular nowadays worldwide and people prefer products which were

*Corresponding author: thevamahen@yahoo.com 
produced organically than inorganically. Application of organic principles enables to increase the usage of local resources, thereby making farming more cost-effective. By using organic fertilizer, healthy plants can be produced while enhancing the sustainability and the fertility of soil. Organic agriculture can contribute to ecologically sustainable, socio-economic development, especially in poor countries (Rachel and Jules, 2007). Organic components such as cow dung, cow urine and molasses help to boost soil microbes and ultimately enhance the yield and quality of the harvest.

Groundnut is considered as a rich source of oil, protein and mineral contents and therefore knowledge in the nutritive value of groundnut will be important in the processing of ground nut for industrial usage (Ahmed and Young, 1982). Several studies have been conducted to analyze the kernel composition. The major fatty acid composition and physical characteristics of the oils of groundnut had been investigated (Anyasor et al. 2009). Physico-chemical aspects of the oil crops were studied by Ayoola and Adeyeye (2010). However, no research studies were reports on the composition of organically produced groundnut. Therefore, this study was undertaken to assess the quality of groundnut grown with organic fertilizers and the information will be useful for human nutrients to formulate healthy diet to combat malnutrition. Therefore, the objective of the study was to evaluate the nutritional composition and storage stability of the groundnut seeds grown with organic fertilizer applied at different growth stages.

\section{MATERIALS AND METHODS}

The present study was conducted to evaluate the nutritional composition of groundnut (Arachis hypogaea L.) var Indi cultivated with the added organic fertilizer. The research area was situated between $81^{\circ} 34^{\prime}$ latitude and longitude and $7^{\circ} 48^{\prime}$ longitude. It comes under the agro-ecological zones of low country dry zone of Sri Lanka. Annual average temperature is $30^{\circ} \mathrm{C}$ and annual rain fall is $1600 \mathrm{~mm}$. The soil of experimental site was Sandy Regosols.
Inorganic fertilizer applied to control treatment $\left(\mathrm{T}_{1}\right)$ at the rate of $35 \mathrm{~kg} / \mathrm{ha}$ of urea, $100 \mathrm{~kg} / \mathrm{ha}$ of TSP and $75 \mathrm{~kg} / \mathrm{ha}$ of MOP as basal and 35 $\mathrm{kg} / \mathrm{ha}$ of urea as topdressing at flowering stage. For the treatments from $\mathrm{T}_{2}$ to $\mathrm{T}_{5}$, cattle manure was applied at rate of $10 \mathrm{t} / \mathrm{ha}$ as basal and organic liquid fertilizer known as Amuthakaraisal was sprayed as top dressing. It was prepared by mixing cow dung $(3.5 \mathrm{~kg})$, cow urine $(1.3 \mathrm{~L})$ and molasses $(150 \mathrm{~g})$ in 10 liter water. It was kept under shade for $24 \mathrm{~h}$, later 1 liter fertilizer mixture was diluted in 10 liter water and applied to plants at different growing periods as split dosage.

\section{Experiment was designed in RCBD with the treatments such as:}

$\mathrm{T}_{1}$ - Inorganic fertilizers (Control)

$\mathrm{T}_{2}-$ Amuthakaraisal solution sprayed at 15 days after planting

$\mathrm{T}_{3}-$ Amuthakaraisal solution sprayed at 15, 30 days after planting

$\mathrm{T}_{4}-$ Amuthakaraisal solution sprayed at 15, 30, 45 days after planting

$\mathrm{T}_{5}-$ Amuthakaraisal solution sprayed at 30,45 days after planting

\section{Nutritional analysis of groundnut kernels}

After harvest, groundnut was shelled manually and seeds were sun dried for $3 \mathrm{~h}$. Later the seeds were dried in an oven at $100-105^{\circ} \mathrm{C}$ for 6 h. After the red skins were removed by squeezing and stored in an airtight bottle for further analysis. The nitrogen content was determined by the Kjeldahl method (Gallenkamp, Fistreem International Ltd, UK) and it was converted to protein by multiplying by 6.25 . The fat was extracted from the seed flours by Soxhlet extraction method (Sigma-Aldrich, UK) using petroleum ether $\left(40-60^{\circ} \mathrm{C}\right)$ for $6 \mathrm{~h}$. The nutritional composition such as moisture, mineral, fiber, total soluble solids and the physicochemical characteristics of the seed oil for acid value and saponification value were estimated using the standard methods (AOAC, 2000). The data were statistically analyzed, significant differences between the treatments were determined using analysis of variance (ANOVA) 
using SAS software version 9.1 and the treatment means were separated using Duncan's Multiple Range Test at 5\% level.

\section{RESULTS AND DISCUSSION}

\section{Nutritional Characteristics of Groundnut Kernel}

\section{Protein content}

Groundnuts are considered as one of the best nourishing food of the world. Groundnuts are rich in calories, due to the high fat and protein content. Figure 1 shows the protein content of ground nut grown under different levels of added organic fertilizers. There was a significant difference $(\mathrm{P}<0.05)$ among treatments in protein content. The highest protein content was observed in $\mathrm{T}_{4}(32.12 \%)$ and the lowest was $\mathrm{T}_{2}(27.0 \%)$. The reason for variation may be due to different times of application of organic fertilizer in different treatment. Groundnut provides an inexpensive source of high quality dietary protein and oil (Ayoola and Adeyeye, 2010).

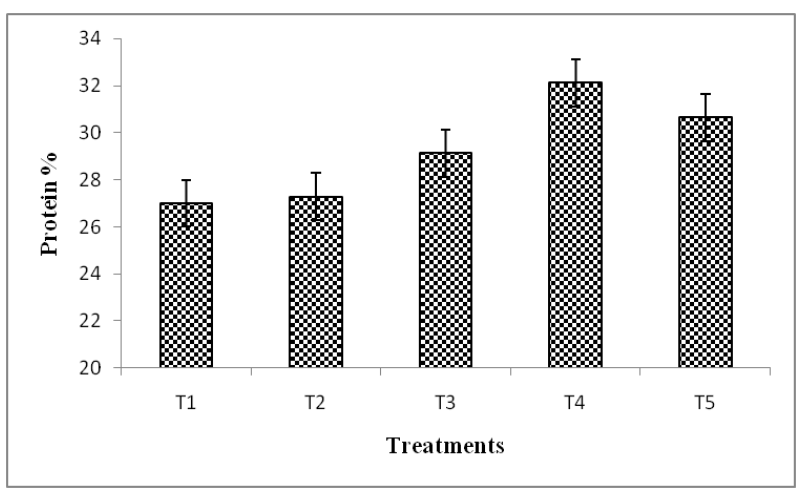

Figure 1: Protein Content of Groundnuts grown under different Organic conditions

Groundnut protein is easily digestible and has high biological value (Shakuntala and Shadaksharaswamy, 1995). Groundnut protein contains a large amount of nutritionally essential amino acids, particularly the basic acid agrinine. Nuts are the best source of plant proteins. They are rich in fiber, antioxidants and phyto-nutrients which help protect against cancer and other chronic heart diseases (Pickett, 1941). Eating nuts may play a role in other aspects of general good health as well as heart health. Therefore, split application of organic liquid fertilizer Amuthakaraisal at 15, 30 and 45 days after planting $\left(\mathrm{T}_{4}\right)$ would produce groundnut seeds with high nutritional value and storage stability compared to other tested treatments.

\section{Fat content}

The dietary fat is important as it provides energy and promotes absorption of fat soluble vitamin. As shown in Figure 2, there were a significant differences $(\mathrm{P}<0.05)$ in fat percentage among treatments. The fat content was higher in $\mathrm{T}_{4}(35.85 \%)$ than that of $\mathrm{T}_{1}$ $(35.40 \%)$. However the fat content did not significantly different $(\mathrm{P}>0.05)$ in $\mathrm{T}_{1}$ from that of organic fertilizer applied samples.

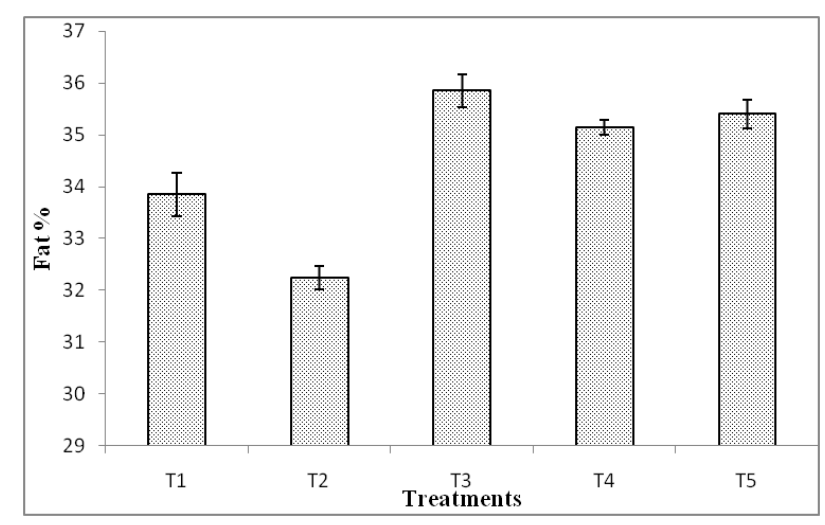

Figure 2: Fat content of Groundnuts grown under different Organic treatments

The oil content of groundnut differs in quantity especially the relative proportion of fatty acids, geographical location, seasons and growing conditions (Adeyeye and Ajewole, 1992). Woodroof (1983) stated that groundnut naturally contains $47-50 \%$ oil. This makes it potential sources of edible oil. The ground nut oil has an anti-oxidant and a chemical called resveratrol. They help in reducing the risk of contracting cardiovascular diseases, cancer risk and also help in anti-ageing. The ground nut oil contains heart-friendly mono- 
unsaturated fatty acids that can lower the levels of harmful cholesterol in human body without lowering the levels of beneficial cholesterol. Its major component fatty acids are oleic acid $(56.6 \%)$ and linoleic acid $(26.7 \%)$. Odoemelam (2005) reported that edible oils from plants provide characteristic flavors and textures to foods as integral diet components.

\section{Nutritional Composition of the Groundnut Seeds}

The nutritional composition of the ground nut kernels are presented in Table 1 . There was no significant difference $(\mathrm{P}>0.05)$ among treatments in moisture content. The moisture of kernel ranged from $5.55 \%\left(\mathrm{~T}_{4}\right)$ to $6.05 \%$ $\left(\mathrm{T}_{1}\right)$. The moisture content of stored raw

Table 1: Nutritional composition of groundnuts grown at different organic conditions

\begin{tabular}{lllll}
\hline $\begin{array}{l}\text { Treat- } \\
\text { ments }\end{array}$ & $\begin{array}{l}\text { Mois- } \\
\text { ture (\%) }\end{array}$ & $\begin{array}{l}\text { Ash } \\
(\%)\end{array}$ & $\begin{array}{l}\text { Fiber } \\
(\%)\end{array}$ & $\begin{array}{l}\text { TSS } \\
\left({ }^{\circ} \text { Brix) }\right.\end{array}$ \\
\hline $\mathbf{T}_{\mathbf{1}}$ & $6.05 \pm$ & $3.66 \pm$ & $2.21 \pm$ & $25 \pm 1^{\mathrm{b}}$ \\
& 0.35 & 0.06 & $0.001^{\mathrm{ab}}$ & \\
$\mathbf{T}_{\mathbf{2}}$ & $5.70 \pm$ & $3.02 \pm$ & $2.21 \pm$ & $28 \pm 0^{\mathrm{a}}$ \\
& 0.30 & 0.58 & $0.010^{\mathrm{ab}}$ & \\
$\mathbf{T}_{\mathbf{3}}$ & $5.85 \pm$ & $3.85 \pm$ & $2.19 \pm$ & $14 \pm 0^{\mathrm{d}}$ \\
& 0.25 & 0.65 & $0.005^{\mathrm{b}}$ & \\
$\mathbf{T}_{\mathbf{4}}$ & $5.55 \pm$ & $3.86 \pm$ & $2.21 \pm$ & $17 \pm 1^{\mathrm{c}}$ \\
& 0.15 & 0.35 & $0.005^{\mathrm{ab}}$ & \\
$\mathbf{T}_{\mathbf{5}}$ & $6.00 \pm$ & $3.48 \pm$ & $2.23 \pm$ & $11 \pm 1^{\mathrm{e}}$ \\
& 0.80 & 0.05 & $0.005^{\mathrm{a}}$ & \\
$\mathbf{F}^{*}$ test & $\mathrm{ns}$ & $\mathrm{ns}$ & $*$ & $* *$ \\
\hline
\end{tabular}

Value represents mean \pm standard error of five replicates.

$\mathrm{F}$ test:**: $\mathrm{P}<0.01 ; \mathrm{P}<0.05$

Means followed by the same letter in each column are not significantly different according to Duncan's Multiple Range Test at 1\% level.

$\mathrm{T}_{1}$-Inorganic fertilizers (Control); $\mathrm{T}_{2}-$ Amuthakaraisal solution sprayed at 15 days after planting; $\mathrm{T}_{3}-$ Amuthakaraisal solution sprayed at 15,30 days after planting; $\mathrm{T}_{4}-$ Amuthakaraisal solution sprayed at $15,30,45$ days after planting and $\mathrm{T}_{5}$-Amuthakaraisal solution sprayed at 30,45 days after planting. groundnut varies from 5.2 to $7.3 \%$ (Woodroof, 1983).

Mineral content ranged between 3.02\% $\left(\mathrm{T}_{2}\right)$ to $3.86 \%\left(\mathrm{~T}_{4}\right)$. Woodroof (1983) reported that groundnut contains about $3 \%$ ash, with about $4 \%$ in the groundnut meal. Ash content shows the total amount of minerals present within a groundnut. Groundnut provides considerable amounts of mineral elements to supplement the dietary requirements of human (Asibuo et $a l ., 2008)$. There was no significant difference $(\mathrm{P}>0.05)$ among treatments (Table: 1). Low level of ash content indicates low level of minerals. Moisture and ash contents are similar to the reports of Atasic, et al. (2009). In this study, organic fertilizer applied treatments indicated the highest level of ash content compared to inorganic fertilizer applied treatment $\left(\mathrm{T}_{1}\right)$. Nuts also add other essential minerals to the diet, including calcium, manganese, magnesium, zinc, iron, chromium, phosphorous and folate that help in brain function and development as well as strong skeletal system.

Crude fiber is vital for maintain regular intestinal peristalsis movements. Low amount of crude fiber in diets makes several problems, such as constipation, colonal cancer etc. There was a significant difference $(\mathrm{P}<0.05)$ among treatments in crude fiber (Table: 1$)$. It ranges from $2.19 \%\left(\mathrm{~T}_{3}\right)$ to $2.23 \%\left(\mathrm{~T}_{5}\right)$. Total soluble solid (TSS) provides sweetness of food. There was a significant difference $(\mathrm{P}<0.01)$ in TSS among tested treatments. The highest value of $28^{\circ}$ Brix was observed in the $\mathrm{T}_{2}$ treatment whereas the lowest value of $11^{\circ}$ Brix was noted in the $\mathrm{T}_{5}$ treated ground nut seeds.

\section{Physico-chemical Properties of the Groundnut Oil}

Groundnut kernels are composed of approximately equal weights of fatty and non-fatty constituents (Woodroof, 1983). The characteristics of the ground nut oil are given in Table:2. 
Table 2: Characteristics of organically grown groundnut oil

\begin{tabular}{ll}
\hline Characteristics & Content \\
\hline Appearance & Clear and bright \\
Free-fatty acid & $\leq 0.5 \%$ \\
Peroxide value & $\leq 3$ max. (meq $/ \mathrm{kg})$ \\
Colour & Max. 2 Red \\
Iodine value & $70-95$ \\
$\begin{array}{l}\text { Saponification } \\
\text { value }\end{array}$ & $135-261 \mathrm{mg} \mathrm{KOH} / \mathrm{g}$ of oil \\
Odour and flavor & Free from rancid odours and flavours \\
\hline
\end{tabular}

Value represents means of three replicates.

The saturated acid present in the largest quantity in groundnut oil is palmitic acid (Blank, 1999). As indicated in the Table 3, there were significant differences $(\mathrm{P}<0.01)$ among treatments in saponification value of the ground nut oil. It ranged from $135.3\left(\mathrm{~T}_{2}\right)$ to $216.3 \mathrm{mg}$ $\mathrm{KOH} / \mathrm{g}$ of oil $\left(\mathrm{T}_{4}\right)$. Saponification value of groundnut was reported as $195 \mathrm{mg} \mathrm{KOH} / \mathrm{g}$ of oil by Ayoola and Adeyeye (2010).

A high number of saponification values indicate that fat is made up of low molecular weight fatty acids and it is more suitable to use as edible oil in food applications. (Denniston et al. 2004). Therefore these results indicate that organically produced ground nut contains more short chain fatty acids than the ground nuts produced inorganically. Remarkably, groundnut oil manages to retain quite a luscious taste that makes it the preferred oil for chefs all over the world. This pale coloured oil with a light consistency is used extensively for deep-frying since it can be heated to a high temperature $\left(229.4^{\circ} \mathrm{C}\right)$ without burning.

The acid value of the ground nut oil is used as a measure of quality. However, the acid value of the oil must not be too high, as this denotes an excessively high content of free fatty acids, which causes the oil to turn sour and dis- coloured. Peanut oil has an acid value of at most $<4.0 \%$. Ayoola and Adeyeye, (2010) found that the acid value of sun dried and roasted groundnut oil were 1.79 and $2.52 \%$, respectively. In our experiments, the acid value significantly varied $(p<0.01)$ among the tested treatments and the results are shown in Table 3.

Table 3: Saponification value and Acid value of groundnut oil at different treatments

\begin{tabular}{lll}
\hline $\begin{array}{l}\text { Treat- } \\
\text { ments }\end{array}$ & $\begin{array}{c}\text { Saponification Value } \\
(\mathbf{m g ~ K O H} / \mathbf{g})\end{array}$ & $\begin{array}{c}\text { Acid Value } \\
(\%)\end{array}$ \\
\hline $\mathbf{T}_{\mathbf{1}}$ & $138.4 \pm 0.5^{\mathrm{d}}$ & $0.56 \pm 0.00^{\mathrm{d}}$ \\
$\mathbf{T}_{\mathbf{2}}$ & $135.3 \pm 1.0^{\mathrm{e}}$ & $1.60 \pm 0.05^{\mathrm{b}}$ \\
$\mathbf{T}_{\mathbf{3}}$ & $141.0 \pm 0.5^{\mathrm{c}}$ & $2.24 \pm 0.01^{\mathrm{a}}$ \\
$\mathbf{T}_{\mathbf{4}}$ & $216.3 \pm 0.5^{\mathrm{a}}$ & $0.52 \pm 0.00^{\mathrm{e}}$ \\
$\mathbf{T}_{\mathbf{5}}$ & $188.5 \pm 0.5^{\mathrm{b}}$ & $1.12 \pm 0.01^{\mathrm{c}}$ \\
$\mathbf{F}$ test & $* *$ & $* *$ \\
\hline
\end{tabular}

Value represents mean \pm standard error of five replicates.

F test:*: $\mathrm{P}<0.01$.

Means followed by the same letter in each column are not significantly different according to Duncan's Multiple Range Test at 1\% level.

$\mathrm{T}_{1}$ - Inorganic fertilizers (Control); $\mathrm{T}_{2}-$ Amuthakaraisal solution sprayed at 15 days after planting; $\mathrm{T}_{3}-$ Amuthakaraisal solution sprayed at 15, 30 days after planting; $\mathrm{T}_{4}-$ Amuthakaraisal solution sprayed at $15,30,45$ days after planting and $\mathrm{T}_{5}-$ Amuthakaraisal solution sprayed at 30 , 45 days after planting.

The highest acid value was obtained in the $\mathrm{T}_{3}$ $(2.24 \%)$ and the lowest in $\mathrm{T}_{4}(0.52 \%)$ treatments. It clearly indicates that the seeds obtained from the $\mathrm{T}_{4}$ treatment have less chance for rancidity during processing and storage. Sri Lakshmi (2001) reported that groundnut oil has excellent oxidative stability comprising $20 \%$ saturated, 54\% mono-unsaturated and $26 \%$ poly-unsaturated fatty acid. Increasing split dosage and application of Amuthakaraisal until flowering (15, 30 and 45 days after planting) reduced rancidity and increase storage stability of seeds. 


\section{CONCLUSIONS}

The present study concluded that protein content was significantly higher $(\mathrm{P}<0.01)$ among the tested organic treatments. It was observed that the highest protein content $(32.12 \%)$ in the treatment $4\left(\mathrm{~T}_{4}\right)$. Crude fat and fiber contents of groundnut kernel were significantly varied $(\mathrm{P}<0.05)$ among tested treatments and there were no significant differences $(\mathrm{P}>0.05)$ between inorganic and organic treatments. It was also noticed that there were no significant differences $(\mathrm{P}>0.05)$ among treatment in moisture and mineral contents. Acid value and saponification value of the oil were highly significant $(\mathrm{P}<0.01)$ among treatments. The acid value and saponification value of the $\mathrm{T}_{4}$ treated crops were $0.52 \%$ and $216.3 \mathrm{mg} /$ $\mathrm{KOH} / \mathrm{g}$ respectively. Therefore, this study revealed that the application of cattle manure (10 t/ha) as basal and organic liquid fertilizer namely Amuthakaraisal sprayed at 15, 30, 45 days after planting as top dressing $\left(\mathrm{T}_{4}\right)$ would be the most suitable treatment to obtain high quality groundnut seeds which have potential to make different food with high nutrients and the research findings would be important for the preparation of balance diet to overcome malnutrition problems.

\section{REFERENCES}

Adeyeye A and Ajewole K 1992 Chemical composition and fatty acid profiles of cereals in Nigeria. Food Chem. 44: 4144.

Ahmed EH and Young CT 1982 Composition of nutrients and flavor profile of peanut. In: Peanut Science and Technology. Patee HE and Young CT (Eds.) American Peanut Research and Education Society, Inc. USA. pp. 655-687.

Anyasor GN, Ogunwenmo KO, Oyelana OA, Ajayi D and Dangana J 2009 Chemical analyses of Groundnut (Arachis hypogaea) oil. Pak. J. Nutr. 8(2): 269272.
AOAC. 2000 Official Method of Analysis. $17^{\text {th }}$ Edn. Association of Official Analytical Chemists. Washington, USA. pp 8-14.

Asibuo JY, Akromah R, Safo-Kantanka O, OseiAdu-Dapaah OS, Hans $\mathrm{K}$ and Agyeman A 2008 Chemical composition of groundnut, Arachis hypogaea (L) land races. Afr. J. Biotech.7: 203208.

Atasie VN, Akinhanmi TF and Ojiodu CC 2009 Proximate analysis and physicchemical properties of groundnut (Arachis hypogaea L.). Pak. J. Nutr. 8 (2): 194-197.

Ayoola PB and Adeyeye A 2010. Effect of heating on the chemical composition and Physico-chemical properties of Arachis hypogea (Groundnut) seed flour and oil. Pak. J. Nutr. 9(8): 751754.

Bansal UK, Satija DR and Ahuja KL 1993 Oil composition of diverse groundnut (Arachis hypogaea L.) genotypes in relation to different environment. J. Sci. Food Agri. 63: 17-19.

Blank F 1999 Hand Book of Food and Nutrition. Agro Botanical Publishers, UK. pp. 85-89.

Denniston KJ, Topping JC and Caret RL 2004 General Organic and Biochemistry. McGraw Hill Companies, New York, USA. pp. 432-433.

Odoemelam SA 2005 Proximate Composition and selected physico-chemical properties of the seeds of African oil bean (Pentaclethra marcrophylla). Pak. J. Nutr. 4(4): 382-383.

Pickett TA 1941 Vitamins in peanuts. Georgia Groundnut Experimental Station Circular No: 128: pp 1-43.

Rachel H and Jules P 2007 Organic Agriculture: Sustainability and Food Security in East Africa. University of Essex, UK. pp 1-55.

Savage GP and Keenan JI 1994 Composition and nutritive value of groundnut ker- 
nels. In: Scientific basis for improvement of groundnut. Smart JC (Ed). Chapman and Hall, London. UK. pp. 173-213.

Shakuntala $M$ and Shadaksharaswamy $M$ 1995 Foods Facts and Principles. New Age International (Pvt.) Ltd., India. pp 315-317.

Sri Lakshmi B 2001 Food Science. New Age International (Pvt.) Ltd, India. pp 182202.

Woodroof JG 1983 Peanut production, processing and storage. AVI Publishing Company, West port, Connecticut, USA. pp 165-179. 